\title{
GLACIOKRAS LOVČENA
}

\section{Uroš Stepišnik, Manja Žebre: Glaciokras Lovče- na. Zbirka E-GeograFF 2. Znanstvena založba Filozofske fakultete in Oddelek za geografijo, 82 str. Ljubljana, 20 I I}

V elektronski verziji znanstvenih monografij (E-GeograFF) sta v letošnjem letu izšli dve knjigi s krasoslovno tematiko: prva je posvečena specifičnemu tipu kraškega površja v gorovju Lovčen v Črni gori. Tu se na svojski način prepletata dva geomorfna sistema - globoki kras z močno kraško razjedenim površjem visoko nad Boko kotorsko in pleistocenska poledenitev, ki je na tem delu dinarskega krasa prav tako pustila izrazit pečat.

Monografija je diplomsko delo Manje Žebre, ki ga je izdelala pod mentorstvom dr. Uroša Stepišnika ter zanj v letošnjem letu dobila tudi univerzitetno Prešernovo nagrado. To je doslej najcelovitejše delo o pleistocenski poledenitvi Lovčena, za katerega je značilen poseben tip površja (glaciokras), ki so ga hkrati preoblikovali kraški in glacialni procesi. Je pomemben prispevek k poglabljanju poznavanja specifičnih značilnosti pleistocenske poledenitve v Dinarskem gorstvu, temelji pa na obsežnem in natančnem terenskem preučevanju v izjemno zahtevnih razmerah. Dobljene ugotovitve so tudi pomemben prispevek k dosedanjemu védenju o pleistocenskih poledenitvah v gorskem svetu na območju celotnega Sredozemlja, ki so bile očitno precej različne od 'klasičnih' poledenitev v alpskem svetu.

Delo je razdeljeno na pet osnovnih poglavij in več podpoglavij, ki si sledijo od orisa osnovnih geografskih in geomorfoloških značilnosti krasa v Črni gori ter glavnih geografskih značilnosti Lovčena do osrednjih dveh, četrtega (Obseg pleistocenske poledenitve na Lovčenu) in petega poglavja (Glaciokras Lovčena). Izkazalo se je, da je bila (vsaj) zadnja poledenitev precej obsežnejša kot se je mislilo doslej. Led je ob višku ledene dobe pokrival ok. $54 \mathrm{~km}^{2}$, sestavljen pa je bil iz osrednjega ledenega pokrova v nadmorski višini 1200 1320 m z maksimalno debelino ok. 300 m, od katerega se je proti nižje ležečim delom (Njeguško in Cetinjsko polje, Boka kotorska) spuščalo več dolinskih ledenikov; eden naj bi segal celo pod današnjo morsko gladino.

Pomembne ugotovitve raziskave se nanašajo še na višino meje večnega snega in ledu med zadnjo ledeno dobo na Lovčenu (po različnih metodah izračunana med 1230 in $1320 \mathrm{~m}$ ) in pa ugotavljanje ostankov starejših poledenitev. Zaradi izjemne razčlenjenosti površja je tovrstno preučevanje zelo težavno, vendar je na podlagi skromnih ostankov sprijetega morenskega materiala na Lovčenu in absolutnih datacijah v drugih delih Dinarskega ter južnejših gorstev moč soditi, da je bilo tudi na Lovčenu še najmanj eno starejše obdobje poledenitve, vendar bo za jasnejšo sliko potrebno še veliko podrobnega terenskega preučevanja.

Zanimivo delo je strokovni in širši javnosti dostopno na spletni strani Oddelka za geografijo (http://geo.ff.uni-lj.si/sites/default/files/glaciokras_lovcena_0.pdf)

\section{Karel Natek}

